\section{Cybernetics and COMPUTER TECHNOLOGIES}

The paper concerns the linear differential game of approaching a cylindrical terminal set. We study the case when classic Pontryagin's condition does not hold. Instead, the modified considerably weaker condition, dealing with the function of time stretching, is used. The latter allows expanding the range of problems susceptible to analytical solution by the way of passing to the game with delayed information. Investigation is carried out in the frames of Pontryagin's First Direct method that provides hitting the terminal set by a trajectory of the conflict-controlled process at finite instant of time. In so doing, the pursuer's control, realizing the game goal, is constructed on the basis of the FilippovCastaing theorem on measurable choice. The outlined scheme is applied to solving the problem of pursuit for two different second-order systems, describing damped oscillations. For this game, we construct the function of time stretching and deduce conditions on the game parameters, ensuring termination of the game at a finite instant of time, starting from arbitrary initial states and under all admissible controls of the evader.

Keywords: differential game, time-variable information delay, Pontryagin's condition, Aumann's integral, principle of time stretching, Minkowski' difference, damped oscillations.

(c) G.Ts. Chikrii, K.I. Rastvorova, 2021
UDC 517.977

DOI:10.34229/2707-451X.21.1.1

\author{
G.TS. CHIKRII, K.I. RASTVOROVA
}

\section{ONE GAME PROBLEM FOR OSCILLATORY SYSTEMS}

Introduction. A number of efficient methods for making decision under conditions of conflict and uncertainty are created in the theory of dynamic games. They are originated in fundamental works of R. Isaacs [1], L.S. Pontryagin [2], N.N. Krasovskii [3], L. Berkovitz [4], A. Friedman [5], O. Hajek [6], B.N. Pshenitchny [7] and their disciples and based on various mathematical ideas respective to availability of information to opposing sides in the course of game There exists a wide range of mechanical, economical and biological processes which can be described by dynamic systems of various kinds, in particular, by the ordinary differential, difference, differencedifferential, integral, integro-differential, partial differential and fractional equations, depending on the process nature [8-11]. Any disturbance, counteraction or uncertainty readily leads to game situation. The book [12] contains various applications of the game methods to solving real problems.

The deciding factor in study of dynamic games is availability of information on current state of the process, its prehistory or various kind discrimination of the counterpart that results in the problems of pursuit-evasion by position or in the class of stroboscopic, quasior $\varepsilon$-strategies.

It was shown that the dynamic game of pursuit with variable information delay is equivalent to certain perfectinformation game with the changed dynamics and terminal set [13], [14]. On the one hand, it opened up possibilities for application of classic methods to analyze the games with delay of information. On the other hand, it made feasible solving problems which are not susceptible for analysis by known methods.

Pontryagin's condition [2] underlying the First Direct method was developed to solve the linear differential games of pursuit. It reflects an advantage of the pursuer over the evader in control resources in terms of the game parameters. However, there is a number of cases in which this condition does not hold, e.g. the problems of soft meeting (simultaneous coincidence of geometric coordinates and velocities of objects), pursuit problems for oscillatory processes or different inertia systems etc [15-17]. 
Analysis of Pontryagin's condition, performed by Nikolskij in [15], enhanced its understanding and contributed to its modification [18]. Establishment of close relation of the modified condition with the transition from the original game with perfect information to an auxiliary game with delayed information [19] gave impetus to the development of efficient approach to solving the pursuit games for which Pontryagin's condition does not hold [20-21]. This approach is usually referred to as the principle of time stretching.

The essence of the time stretching principle lies in the abandoning fresh information about the current control of the evader for the pursuer. It is assumed that information about behavior of the evader arrives with delay, being function of time. In essence, the transition is made from the original game with complete information to the game with the same dynamics and the terminal set, yet with special kind information delay. This delay is a function of time, decreasing as the game trajectory approaches the terminal set and vanishing as it hits the target. The central idea of the time stretching principle consists in introduction of certain function, called the time stretching function, in which terms the time delay is expressed in explicit form. The obtained game with delayed information is analyzed on the basis of its equivalence to the perfect-information game with the changed dynamics. An important point is that Pontryagin's condition for the latter involves the time stretching function.

The time stretching principle proved its efficiency in solving the problems of soft meeting in various cases of second-order dynamics, for which formula for the time stretching function is deduced in explicit form, in their number, for oscillatory processes and in the case of different-kind dynamics of the players [21]. Simple conditions on the games parameters insuring feasibility of the pursuit termination were inferred.

This approach was also applied to analysis of the dynamic games of pursuit, described by a system of general form encompassing a wide range of the functional-differential systems [22]. In particular, the time stretching principle was specified for the integro-differential game and detailed analysis of specific case of such game was made.

Unfortunately, the problem of approach in geometric coordinates for second order systems dropped out of our consideration. Here we try to fill this gap by considering linear systems describing damped oscillations. To begin with, we provide description of the above mentioned approach as applied to the linear differential game.

\section{Principle of time stretching in the linear differential game}

Let the dynamics of conflict-controlled process be defined by the linear system of differential equations

$$
\dot{z}(t)=A z(t)-u(t)+v(t), z(0)=z_{0} .
$$

Here $z \in R^{n}, A$ is a quadratic matrix of order $n$. Controls $u$ and $v$ are picked by the players at each instant of time from the compacts $U$ and $V$, respectively.

We will analyze the game, standing on the pursuer side $(u)$ which goal is in a finite time to bring a trajectory of the system (1) to the terminal set $M_{*}$ under any admissible control of the evader $(v)$. The goal of evader is, with help of its control choice, to avoid a trajectory of the process from meeting the terminal set at the finite instant of time or, if it is impossible, to maximally postpone this meeting.

It is assumed that set $M_{*}$ has a cylindrical form:

$$
M_{*}=M_{0}+M,
$$

$M_{0}$ - being a linear subspace in $R^{n}$ and $M$ - a convex compact from $L$ - the orthogonal complement to $M_{0}$ in $R^{n}$. It is assumed that $z_{0} \notin M_{*}$. 
Let $\pi$ be the operator of orthogonal projection from $R^{n}$ onto $L, \pi: R^{n} \rightarrow L$. Then, hitting the terminal set (2) by a trajectory of (1) at the instant $t$ is equivalent to fulfillment of the inclusion $\pi z(t) \in M$.

To achieve his goal the pursuer applies counter-controls, that is at each current instant of time he constructs its control on the basis of instantaneous control of his counter-part. In so doing, the players choose their controls in a way their realizations in time be Lebesgue measurable functions [23]. We denote by $\Omega_{\mathrm{U}}, \Omega_{\mathrm{V}}$ the sets of Lebesgue measurable functions taking their values in $U$ and $V$, appearing as the sets of all admissible controls of the pursuer and the evader, respectively.

In what follows, the operation of geometric subtraction $*$ by Minkowski is applied [2].

Definition 1. $X * Y=\{z: z+Y \subset X\}=\underset{y \in Y}{\cap}(X-y), X \subset R^{n}, Y \subset R^{n}$. та

Also, in the sequel the notion of Aumann's integral of set-valued mapping is used [24].

Definition 2. Let $F(t)$ be a measurable mapping, $F:\left[t_{0}, T\right] \rightarrow P\left(R^{n}\right)$, where $P\left(R^{n}\right)$ is a set of all closed subsets of the space $R^{n}$. By Aumann's integral of set-valued mapping $F(t)$, usually denoted by $\int_{t_{0}}^{T} F(t) d t$, is meant the union, taken over all its measurable selections $f(t), f(t) \in F(t)$ :

$$
\bigcup_{f(\cdot) \in F(\cdot) t_{0}}^{T} f(t) d t
$$

At the heart of Pontryagin's First Direct Method is condition of the same name [2], [9].

It reflects an instantaneous advantage of the pursuer over the evader in control resources expressed through the game parameters.

Condition 1 (Pontryagin's). Set-valued mapping $W(t)=\pi e^{t A} U \underbrace{t A}_{-\pi} V$ has non-empty images at all $t \geq 0$.

In the cases of failure of Pontryagin's condition, an approach is proposed consisting in abandoning of fresh information on evader's control available to the pursuer. To be specific, passage is made from the original game with complete information to the game with the same dynamics and the terminal set, yet with special kind information delay which is decreasing as the game trajectory approaches the terminal set and turns into zero at the moment when the game trajectory hits the target. The game with delayed information is analyzed on the basis of its equivalence to the perfect-information game with the changed dynamics and terminal set [19-20]. The central idea of investigation consists in introduction of special function - the function of time stretching, in which terms the time delay is expressed.

Definition 3. By the function of time stretching we name a non-negative monotonically increasing function of time $I(t), t \in[0,+\infty), I(0)=0, I(t)>t, t>0$, which can have no more than countable number of discontinuities and all discontinuities are of the first order, absolutely continuous on the intervals of its continuity, and such that $\sup \dot{I}(t)<+\infty$, where $\Delta$ is a set of the discontinuity and non-differentiability points of $I(t)$.

It should be emphasized that the requirement on function $I(t)$ be continuously differentiable [18] essentially narrows the scope of its applications.

Condition 2. There exists a function of time-stretching $I(t)$, such that 


$$
W_{1}(t)=\pi e^{t A} U * \dot{I}(t) \pi e^{I(t) A} V \neq \varnothing \quad \forall t \geq 0 .
$$

Theorem 1. Let the differential game (1), (2) meet Condition 2 and let for the given initial state $z_{0}$ there exist a finite instant of time $t_{1}$ :

$$
t_{1}=t_{1}\left(z_{0}\right)=\min \left\{t \geq 0: \pi\left(e^{I(t) A} z_{0}-\int_{0}^{I(t)-t} e^{(I(t)-\theta) A} U d \theta\right) \cap\left(M+\int_{0}^{t} W_{1}(\theta) d \theta\right) \neq \varnothing\right\} .
$$

Then the game, starting at the initial state $z_{0}$, can be terminated at the time instant $I\left(t_{1}\right)$ under all admissible controls of the evader.

To this end, on the half-interval $\left[0, \tau_{0}\right), \tau_{0}=I\left(t_{1}\right)-t_{1}$, we set control of the pursuer equal to $u^{\tau_{0}}(\theta)$ and on the interval $\left[\tau_{0}, \tau_{0}+t_{1}\right]$ it is built in the form of a measurable solution of the equation

$$
\begin{gathered}
\pi e^{\left(t_{1}-\theta\right) A} u\left(\tau_{0}+\theta\right)= \\
=\dot{I}\left(t_{1}-\theta\right) \pi e^{I\left(t_{1}-\theta\right) A} v\left(I\left(t_{1}\right)-I\left(t_{1}-\theta\right)\right)+\chi_{1}\left(t_{1}-\theta\right), \theta \in\left[0, t_{1}\right] .
\end{gathered}
$$

Control $u^{\tau_{0}}(\theta), \theta \in\left[0, \tau_{0}\right)$, and measurable selection $\chi_{1}(\theta), \theta \in\left[0, t_{1}\right]$, of the set-valued mapping $W_{1}(\theta)$ are determined by Condition 2 relationship (4). It should be noted that a measurable solution of (5) exists by the Filippov-Castaing theorem on measurable choice [25].

Using formula (5) and the relationships (3), (4), one can deduce that $\pi \tilde{z}\left(t_{0}+I\left(t_{1}\right)\right)=m, m \in M$ [20]. Therefore, at the moment $I\left(t_{1}\right)$ the pursuer brings a trajectory of the original game (1) to the terminal set $M_{*}$ for all admissible control of the evader. Thus, at the finite moment of time $I\left(t_{1}\right)$ the game is terminated. In so doing, on the interval $\left[\tau_{0}, \tau_{0}+t_{1}\right]$ the pursuer builds its control relative to the evader's control at the following moment of time in the past

$$
I\left(t_{1}\right)-I\left(t_{1}-\theta\right)=\tau_{0}+\theta-\left(I\left(t_{1}-\theta\right)-\left(t_{1}-\theta\right)\right) .
$$

This testifies that on the interval $\left[\tau_{0}, \tau_{0}+t_{1}\right]$ the pursuer constructs its control in a way as if information on its counter-part behavior is available to with the time delay $I\left(t_{1}-\theta\right)-\left(t_{1}-\theta\right)$ that at the moment $I\left(t_{1}\right)$ turns into zero.

\section{Approaching of two controlled oscillatory motions. Problem statement}

Let us consider differential game, which dynamics is described by two linear differential systems of second order:

$$
\begin{aligned}
& \ddot{x}+2 h_{1} \dot{x}+\gamma_{1}^{2} x=\rho u, \quad x \in R^{n}, \quad\|u\| \leq 1, \quad x(0)=x_{0}, \quad \dot{x}(0)=\dot{x}_{0}, \\
& \ddot{y}+2 h_{2} \dot{y}+\gamma_{2}^{2} y=\sigma v, \quad y \in R^{n}, \quad\|v\| \leq 1, \quad y(0)=y_{0}, \quad \dot{y}(0)=\dot{y}_{0} .
\end{aligned}
$$


Here $x, y$, are geometric states of the pursuer and the evader, respectively, $u$ and $v$ are their controls, parameters $\rho, \sigma$-force coefficients, $h, \gamma_{1}, \gamma_{2}, \rho, \sigma>0$.

Goal of the pursuer is to achieve coincidence of geometric states of the objects at some finite instant of time $t$, i.e. $x(t)=y(t)$.

In the absence of controls influence $(u=0, v=0)$ each of the systems (7), (8) defines free oscillations of a linear system in the presence of viscous friction [26]. The parameter $\gamma_{i}$ defines the natural angular frequency of oscillations. Here we consider the case of low viscous friction, namely, when $\gamma_{i}^{2}>h_{i}^{2}$, $i=1,2$, is the amplitude of the system oscillations. Behavior of each of the systems (7), (8), is determined by the roots of its characteristic equation $s^{2}+2 h s+\gamma^{2}=0$. The damped angular frequency of oscillations of the system with viscous friction is defined by parameter $\omega_{i}, \omega_{i}=\sqrt{\gamma_{i}^{2}-h_{i}^{2}}$ [26]. Thus, systems (7), (8) describe damped oscillations.

We consider the case when

With the help of substitution of variables

$$
\omega_{1}>\omega_{2}
$$

$$
x_{1}=x, \quad x_{2}=\dot{x}, \quad y_{1}=y, \quad y_{2}=\dot{y}
$$

we reduce the systems of equations of second order (7), (8) to the first order system for the variable $z=\left(x_{1}, x_{2}, y_{1}, y_{2}\right)$, under the initial condition $z(0)=z_{0}=\left(x_{0}, \dot{x}_{0}, y_{0}, \dot{y}_{0}\right), z \in R^{4 n}$.

In so doing, the terminal set transforms into a linear subspace of $R^{4 n}$ :

$$
M=\left\{\left(x_{1}, x_{2}, y_{1}, y_{2}\right), x_{1}, x_{2}, y_{1}, y_{2} \in R^{n}: x_{1}=y_{1}\right\} .
$$

Dynamics of the state variable $z(t)$ in $R^{4 n}$ is described by a system of equations of the form (1), where

$$
A=\left(\begin{array}{cccc}
O & E & O & O \\
-\gamma_{1}^{2} E & -2 h_{1} E & O & O \\
O & O & O & E \\
O & O & -\gamma_{2}^{2} E & -2 h_{2} E
\end{array}\right) .
$$

Here $E$ and $O$ are the unit and zero $n \times n$ matrices, respectively.

The sets of control $U$ and $V$ take the forms:

$$
U=\left(\begin{array}{llll}
O & S & O & O
\end{array}\right)^{T}, V=\left(\begin{array}{llll}
O & O & O & S
\end{array}\right)^{T},
$$

where by $S, S \in R^{n}$, is denoted the ball of unit radius centered at the origin.

The orthogonal complement to $M$ in $R^{4 n}$ appears as a subspace of $R^{4 n}$ :

$$
L=\left\{\left(x_{1}, x_{2}, y_{1}, y_{2}\right), \quad x_{1}, x_{2}, y_{1}, y_{2} \in R^{n}: x_{1}=-y_{1}, x_{2}=0, y_{2}=0\right\} .
$$

The operator of orthogonal projection from $R^{4 n}$ on $L$ is defined by the matrix

$$
\pi=\left(\begin{array}{llll}
E & O & -E & O
\end{array}\right) .
$$

We see that the geometric coordinates of objects coincide at the moment $t$ if and only if $\pi z(t)=0$. 
Now we proceed to finding fundamental matrices $e^{t A_{i}}, i=1,2$, of systems (7), (8), respectively. To this end, we solve the following equation

$$
\ddot{x}+2 h_{1} \dot{x}+\gamma_{1}^{2} x=0, \quad x(0)=x_{0}, \dot{x}(0)=\dot{x}_{0} .
$$

It is known from the theory of differential equations that solution of the above equation has the form

$$
x(t)=C_{1} e^{s_{1} t}+C_{2} e^{s_{2} t}, \quad \dot{x}(t)=C_{1} s_{1} e^{s_{1} t}+C_{2} s_{2} e^{s_{2} t}, \quad s_{1,2}=-h_{1} \mp i \omega_{1} .
$$

To find constants $C_{1}, C_{2}$ we set $t=0$ into the formulas (10) and obtain:

$$
x_{0}=C_{1}+C_{2}, \dot{x}_{0}=C_{1} s_{1}+C_{2} s_{2}
$$

whence it follows:

$$
\begin{gathered}
C_{1}=\frac{s_{2}}{s_{2}-s_{1}} x_{0}-\frac{1}{s_{2}-s_{1}} \dot{x}_{0}=\frac{-h+\omega i}{2 \omega i} x_{0}-\frac{1}{2 \omega i} \dot{x}_{0}, \\
C_{2}=-\frac{s_{1}}{s_{2}-s_{1}} x_{0}+\frac{1}{s_{2}-s_{1}} \dot{x}_{0}=\frac{-h-\omega i}{2 \omega i} x_{0}+\frac{1}{2 \omega i} \dot{x}_{0} .
\end{gathered}
$$

We substitute the obtained expressions for $C_{1}$ and $C_{2}$ into formulas (10).

$$
\begin{gathered}
x(t)=\left(\frac{-h_{1}+i \omega_{1}}{2 \omega_{1} i} x_{0}-\frac{1}{2 \omega_{1} i} \dot{x}_{0}\right) e^{\left(-h_{1}-\omega_{1} i\right) t}+\left(\frac{-h_{1}-\omega_{1} i}{2 \omega_{1} i} x_{0}+\frac{1}{2 \omega_{1} i} \dot{x}_{0}\right) e^{\left(-h_{1}+\omega_{1} i\right) t}, \\
\dot{x}(t)=\left(-h_{1}-\omega_{1} i\right)\left(\frac{-h_{1}+\omega_{1} i}{2 \omega_{1} i} x_{0}-\frac{1}{2 \omega_{1} i} \dot{x}_{0}\right) e^{\left(-h_{1}-\omega i\right) t}+ \\
+\left(-h_{1}+\omega_{1} i\right)\left(\frac{-h_{1}-\omega_{1} i}{2 \omega_{1} i} x_{0}+\frac{1}{2 \omega_{1} i} \dot{x}_{0}\right) e^{\left(-h_{1}+\omega_{1} i\right) t} .
\end{gathered}
$$

Then we have

$$
\begin{gathered}
x(t)=e^{-h_{1} t}\left(\left(h_{1} \frac{e^{\omega_{1} i t}-e^{-\omega_{1} i t}}{2 \omega_{1} i}+\frac{e^{\omega_{1} i t}+e^{-\omega_{1} i t}}{2}\right) x_{0}+\left(\frac{e^{\omega_{1} i t}-e^{-\omega_{1} i t}}{2 \omega_{1} i}\right) \dot{x}_{0}\right), \\
\dot{x}(t)=e^{-h_{1} t}\left(\left(-\left(h_{1}^{2}+\omega_{1}^{2}\right) \sin \omega_{1} t\right) x_{0}+\left(-\frac{h_{1}}{\omega_{1}} \sin \omega_{1} t+\cos \omega_{1} t\right) \dot{x}_{0}\right) .
\end{gathered}
$$

Taking into account the formulas $\cos \omega t=\frac{e^{\omega i t}+e^{-\omega i t}}{2}, \sin \omega t=\frac{e^{\omega i t}-e^{-\omega i t}}{2 i}$, from the above expressions we infer that

$$
\begin{gathered}
x(t)=e^{-h_{1} t}\left(\left(\frac{h_{1}}{\omega_{1}} \sin \omega_{1} t+\cos \omega_{1} t\right) x_{0}+\frac{1}{\omega_{1}} \sin \omega_{1} t \cdot \dot{x}_{0}\right), \\
\dot{x}(t)=e^{-h_{1} t}\left(\left(-\left(h_{1}^{2}+\omega_{1}^{2}\right) \sin \omega_{1} t\right) x_{0}+\left(-\frac{h_{1}}{\omega_{1}} \sin \omega_{1} t+\cos \omega_{1} t\right) \dot{x}_{0}\right) .
\end{gathered}
$$

Thus, the fundamental matrix $e^{t A}$ of the united system has the form

$$
e^{t A}=\left(\begin{array}{cc}
e^{t A_{1}} & O \\
O & e^{t A_{2}}
\end{array}\right) .
$$


Here

$$
e^{t A_{i}}=\left(\begin{array}{cc}
e^{-h_{i} t}\left(\frac{h_{i}}{\omega_{i}} \sin \omega_{i} t+\cos \omega_{i} t\right) E & e^{-h_{i} t} \frac{\sin \omega_{i} t}{\omega_{i}} E \\
e^{-h_{i} t}\left(-\frac{\gamma_{i}^{2}}{\omega_{i}} \sin \omega_{i} t\right) E & e^{-h_{i} t}\left(-\frac{h_{i}}{\omega_{i}} \sin \omega_{i} t+\cos \omega_{i} t\right) E
\end{array}\right), i=1,2 .
$$

In view of the formulas (11), the set $W(t)$ (appearing in Condition 1) looks as follows

$$
W(t)=\frac{\rho}{\omega_{1}} e^{-h_{1} t}\left|\sin \omega_{1} t\right| S_{-}^{*} \frac{\sigma}{\omega_{2}} e^{-h_{2} t}\left|\sin \omega_{2} t\right| S .
$$

For the game in study, Pontryagin's condition takes the form

Condition 3. The set-valued mapping $W(t)$ has non-empty images on the whole semi-axis $[0,+\infty)$, i.e. $W(t) \neq \varnothing \forall t \geq 0$.

One can observe that Condition 3 is provided by the following inequality

$$
\frac{\rho}{\omega_{1}} e^{-h_{1} t}\left|\sin \omega_{1} t\right|-\frac{\sigma}{\omega_{2}} e^{-h_{2} t}\left|\sin \omega_{2} t\right| \geq 0 \quad \forall t \geq 0 .
$$

It should be noted that this inequality can be fulfilled only periodically in time and under very strict conditions on the parameters of systems (see, for example, [16]). Thus, Pontryagin's condition does not hold here.

\section{Application of the principle of time stretching to solve the problem in study}

Here we derive conditions on the game parameters insuring feasibility for the pursuer to achieve its goal at a finite instant of time. To this end, we apply the principle of time stretching, outlined in the previous section.

In what follows, we specify Condition 2 for the game in study and construct an appropriate function $I(t)$, which meets this condition. In the case under study the set-valued mapping $W_{1}(t)$ has the following form.

$$
W_{1}(t)=\frac{\rho}{\omega_{1}} e^{-h_{1} t}\left|\sin \omega_{1} t\right| S_{-}^{*} \frac{\sigma}{\omega_{2}} \dot{I}(t) e^{-h_{2} I(t)}\left|\sin \omega_{2} I(t)\right| S
$$

Condition 4. There exists function of time stretching $I(t)$, such that

$$
W_{1}(t) \neq \varnothing \quad \forall t \geq 0 .
$$

Condition 4 can be reduced to the relationship which should hold on the whole semi-axis $[0,+\infty)$ :

$$
\frac{\rho}{\omega_{1}} e^{-h_{1} t}\left|\sin \omega_{1} t\right|-\frac{\sigma}{\omega_{2}} \dot{I}(t) e^{-h_{2} I(t)}\left|\sin \omega_{2} I(t)\right| \geq 0, \quad \forall t \geq 0 .
$$

Now we proceed to constructing the time stretching function $I(t)$, such that

$$
\left|\sin \omega_{2} I(t)\right|=\left|\sin \omega_{1} t\right|, t \in[0,+\infty) .
$$


Let us take advantage of the relationship (14) and set

$$
I(t)=\frac{\omega_{1}}{\omega_{2}} t, t \geq 0
$$

One can see that $I(t)$ meets all requirements imposed on the function of time stretching because $I(0)=0, I(t)>t$ for $t>0$ and $\dot{I}(t)=\frac{\omega_{1}}{\omega_{2}}$.

Upon substitution $I(t)=\frac{\omega_{1}}{\omega_{2}} t$ into relation (13) we obtain the inequality

$$
\frac{\rho}{\omega_{1}} e^{-h_{1} t}\left|\sin \omega_{1} t\right|-\frac{\omega_{1}}{\omega_{2}} \frac{\sigma}{\omega_{2}} e^{-h_{2} \frac{\omega_{1}}{\omega_{2}} t}\left|\sin \omega_{1} t\right| \geq 0 .
$$

The latter yields the relationship

$$
\frac{\rho}{\omega_{1}} e^{-h_{1} t}-\frac{\omega_{1}}{\omega_{2}} \frac{\sigma}{\omega_{2}} e^{-h_{2} \frac{\omega_{1}}{\omega_{2}} t} \geq 0 .
$$

Let us assume that the following conditions on the game parameters are fulfilled:

$$
\begin{aligned}
h_{2} \omega_{1} & \geq h_{1} \omega_{2}, \\
\frac{\rho}{\omega_{1}^{2}} & \geq \frac{\sigma}{\omega_{2}^{2}} .
\end{aligned}
$$

It is evident that, under these conditions, inequality (16) is fulfilled and Condition 4 holds.

Using the previous reasoning we come to the following conclusion. If conditions (9), (17), (18) on the game parameters are fulfilled then for the time stretching function (15) Condition 4 holds true. Thus, the first assumption of Theorem 1 concerning existence of the appropriate time stretching function, is fulfilled.

It remains to show that for all initial states of the conflict-controlled systems (7), (8) there exists a finite moment of time $t_{1}$, such that the assumption (4) of Theorem 1 holds true. Therewith, the time stretching function $I(t)$ is given by the formula (15).

Let us set control of the pursuer $u^{0}(\theta) \equiv 0, \theta \in\left[0, \tau_{0}\right)$, where $\tau_{0}=I\left(t_{1}\right)-t_{1}$. Then we have to prove existence of the moment $t_{1}$, defined by the formula

$$
\pi e^{I(t) A} z_{0} \in \int_{0}^{t} W_{1}(\theta) d \theta
$$

The time $t_{1}$ is the first moment $t$, at which the following inclusion is fulfilled:

$$
\begin{gathered}
\left(e^{-h_{1} I(t)}\left(\frac{h_{1}}{\omega_{1}} \sin \omega_{1} I(t)+\cos \omega_{1} I(t)\right) E, \frac{\sin \omega_{1} I(t)}{\omega_{1}} E\right)\left(\begin{array}{c}
x_{0} \\
\dot{x}_{0}
\end{array}\right)- \\
-\left(e^{-h_{2} I(t)}\left(\frac{h_{2}}{\omega_{2}} \sin \omega_{2} I(t)+\cos \omega_{2} I(t)\right) E, \frac{\sin \omega_{2} I(t)}{\omega_{2}} E\right)\left(\begin{array}{l}
y_{0} \\
\dot{y}_{0}
\end{array}\right) \in \int_{0}^{t} W_{1}(\theta) d \theta .
\end{gathered}
$$


As time $t$ grows, the vector, standing at the left-hand of the inclusion (19), does not leave certain ball $r S, r S \in R^{n}$, of radius $r$, centered at the origin. From previous considerations there follows that the set, standing at the right-hand side of the inclusion (19) has the following form

$$
\int_{0}^{t} W_{1}(\theta) d \theta=\int_{0}^{t}\left(\frac{\rho}{\omega_{1}} e^{-h_{1} \theta}-\frac{\omega_{1}}{\omega_{2}} \frac{\sigma}{\omega_{2}} e^{-h_{2} \frac{\omega_{1}}{\omega_{2}} \theta}\right)\left|\sin \omega_{1} \theta\right| d \theta \cdot S .
$$

As time tends to infinity the radius of this ball is converging zero. Therefore, assumption (4) of the theorem is not fulfilled. That is why we set $h_{1}=h_{2}=0$.

In this case

$$
\int_{0}^{t} W_{1}(\theta) d \theta=\omega_{1}\left(\frac{\rho}{\omega_{1}^{2}}-\frac{\sigma}{\omega_{2}^{2}}\right) \int_{0}^{t}\left|\sin \omega_{1} \theta\right| d \theta \cdot S,
$$

which in its turn contains the set

$$
\bar{W}_{1}(t)=\omega_{1}\left(\frac{\rho}{\omega_{1}^{2}}-\frac{\sigma}{\omega_{2}^{2}}\right)^{\left[\frac{t}{\pi / \omega_{1}}\right]} \sum_{k=1}^{\pi / \omega_{1}} \int_{0} \sin \omega_{1} \theta d \theta \cdot S .
$$

Here by the sign [.] is denoted the integer part of a number. In view of condition (18), it is easy to show that the set $\overline{W_{1}}(t)$ presents itself the ball

$$
2\left(\frac{\rho}{\omega_{1}^{2}}-\frac{\sigma}{\omega_{2}^{2}}\right)\left[\frac{t}{\pi / \omega_{1}}\right] \cdot S .
$$

As $t \rightarrow+\infty$ this ball tends to the ball of infinite radius centered at the origin. Therefore, at some finite moment of time $t_{1}$ the set $\bar{W}_{1}(t)$ absorbs the ball $r S$ and the inclusion (19) holds true.

Hence, both assumptions of Theorem 1 are fulfilled. From this theorem there follows that in the case $h_{1}=h_{2}=0$ the pursuer can achieve meeting with the evader at some finite moment of time $I\left(t_{1}\right)$, for arbitrary initial states and all admissible controls of the evader. In so doing, the pursuer constructs its control on the basis of control of the evader in the past.

\section{Conclusion}

On the basis of equivalence of the linear differential game of pursuit with variable delay of information to certain perfect information game we substantiated the time stretching principle to study linear game problem of pursuit with complete information, for which classic Pontryagin's condition, reflecting an advantage of the pursuer over the evader in control resources, does not hold. The timestretching modification of Pontryagin's condition, forms a basis for the time stretching principle. The definition of the time stretching function, introduced in the paper, made it feasible to expand the range of problems susceptible to analytical solution, in particular, at the account of the oscillatory systems. Using the time stretching principle we deduced sufficient conditions for guaranteed meeting at a finite instant of time of the objects, performing damped oscillations. They have forms of simple relationships for system parameters and make it feasible to achieve the game goal, under arbitrary initial states of the players and for all admissible controls of the evader. The time-stretching principle offers promise as an efficient tool for probing complicated problems of conflict counteraction of moving objects. 


\section{References}

1. Isaacs R.F. Differential Games. New York-London-Sydney: Wiley Interscience, 1965. 479 p.

2. Pontryagin L.S. Selected Scientific Papers, 2. Moscow: Nauka, 1988. 576 p. (in Russian)

3. Krasovskii N.N. Game Problems on the Encounter of Motions. Moscow: Nauka, 1970. 420 p. (in Russian)

4. Berkovitz L.D. Differential games of generalized pursuit and evasion. SIAM, Control and Optimization. 1986. 24 (53). P. 361-373. https://doi.org/10.1137/0324021

5. Friedman A. Differential Games. New York: Wiley Interscience, 1971. 350 p.

6. Hayek O. Pursuit Games. New York: Academic Press, 1975. 266 p.

7. Pshenitchny B.N. $\varepsilon$-strategies in Differential Games, Topics in Differential Games. New York, London, Amsterdam: North Holland Publ. Co., 1973. P. 45-99.

8. Pshenitchnyi B.N., Chikrii A.A., Rappoport J.S. Group pursuit in differential games. J. Leipzig Techn High School. 1982. P.13-27.

9. Nikolskij M.S. L.S. Pontryagin's First Direct Method in Diffential Games. Izdat. Gos Univ., Moscow. 1984. 65 p. (in Russian)

10. Chikrii A.A., Eidelman S.D. Game problems for fractional quasi-linear systems. Computers and Mathematics with Applications. 2002. 44 (7). P. 835-851. https://doi.org/10.1016/S0898-1221(02)00197-9

11. Dziubenko K.G., Chikrii A.A. An approach problem for a discrete system with random perturbations. Cybernetics and Systems Analysis. 2010. 46 (2). P. 271-281. https://doi.org/10.1007/s10559-010-9204-3

12. Siouris G. Missile Guidance and Control Systems. NewYork: Springer-Verlag, 2004. 666 p.

13. Chikrii G.Ts. On a problem of pursuit under variable information time lag on the availability of a state vector. Dokl. Akad. Nauk Ukrainy. 1979. 10. P. 855-857. (in Russian)

14. Chikrii G.Ts. An approach to solution of linear differential games with variable information delay. Journal of Automation and Information Sciences. 1995. 27 (3-4). P. 163-170.

15. Nikolskij M.S. Application of the first direct method in the linear differential games. Izvestia Akad. Nauk SSSR. 1972. 10 (17). P. 51-56. (in Russian)

16. Chikrii A.A. Conflict-Controlled Processes. Boston, London, Dordrecht: Springer Science \& Business Media, 2013. $424 \mathrm{p}$.

17. Mezentsev A.V. On some class of differential games. Izvestia AN SSSR, Techn. kib. 1971. 6. P. 3-7. (in Russian)

18. Zonnevend D. On one method of pursuit. Doklady Akademii Nauk SSSR. 1972. 204 (6). P. 1296-1299. (in Russian)

19. Chikrii G.Ts. Using impact of information delay for solution of game problems of pursuit. Dopovidi Natsional'noi Akademii Nauk Ukrainy. 1999. 12. P. 107-111.

20. Chikrii G.Ts. Using the effect of information delay in differential pursuit games. Cybernetics and Systems Analysis. 2007. 43 (2). P. 233-245. https://doi.org/10.1007/s10559-007-0042-x

21. Chikrii G.Ts. Principle of time stretching in evolutionary games of approach. Journal of Automation and Information Sciences. 2016. 48 (5). P. 12-26. https://doi.org/10.1615/JAutomatInfScien.v48.i5.20

22. Chikrii G.Ts. Principle of time stretching for Motion Control in Condition of Conflict. Chapter in the book "Advanced Control Systems: Theory an Applications", River Publishers, 2021. P. 52-82.

23. Kolmogorov A.N., Fomin S.V. Elements of Theory of Functions and Functional Analysis. Moscow: Nauka, 1989. 624 p. (in Russian)

24. Aumann R.J. Integrals of set-valued functions. J. Math. Anal. Appl. 1965. 12. P. 1-12. https://doi.org/10.1016/0022247X(65)90049-1

25. Filippov A.F. Differential equations with discontinuous righthand sides. Dordrecht, Boston: Kluwer Publishers, 1988. 258 p. https://doi.org/10.1007/978-94-015-7793-9

26. Vasilenko N.V. Theory of Oscillations. Kiev: Vyshcha Shkola, 1992. 430 p. (in Russian)

Received 18.03.2021

Greta Ts. Chikrii,

Doctor in physics and mathematics, leading scientific researcher, V.M. Glushkov Institute of Cybernetics of NAS of

Ukraine, Kyiv,

g.chikrii@gmail.com

https://orcid.org/0000-0003-2651-0685

\section{Ksenia I. Rastvorova,}

student, The National Technical University of Ukraine "Igor Sikorsky Kyiv Polytechnic Institute". 
УДК 517.977

Г.Ц. Чикрій ${ }^{1}$, К.І. Растворова ${ }^{2}$

\section{Про одну ігрову задачу для коливних систем}

${ }^{1}$ Інститут кібернетики імені В.М. Глушкова НАН України, Київ

${ }^{2}$ Національний технічний університет Украйни «Київський політехнічний інститут імені Ігоря Сікорського»

* Листування: g.chikrii@gmail.com

Вступ. В роботі розглядається ігрова задача про зближення конфліктно-керованого процесу 3 термінальною множиною циліндричного типу у випадку динаміки, що описується системою лінійних диференціальних рівнянь. Проведений аналіз ролі класичної умови Л.С. Понтрягіна при розв'язанні цієї задачі прямими методами, зокрема однойменним першим прямим методом. Докладно досліджується ігрова задача про зближення двох згасаючих коливань.

Мета роботи. На базі еквівалентності лінійної диференціальної гри із змінним запізненням інформації грі з повною інформацією обгрунтувати принцип розтягу часу для вирішення задач 3 повною інформацією, для яких не виконується умова про перевагу над супротивником в ресурсах керування. Розширити поняття функції розтягу часу на клас розривних функцій з метою його подальшого використання при вирішенні складних ігрових задач.

Результати. Застосовуючи принцип розтягу часу, на базі першого прямого методу Понтрягіна одержані достатні умови зближення в лінійних диференціальних іграх, для яких не виконана умова миттєвої переваги в ресурсах керування. Одержані достатні умови виведення траєкторії конфліктнокерованої системи на термінальну множину в скінченний момент часу. Ці умови конкретизовані для ігрової задачі про зближення двох згасаючих коливань, динаміка яких описується системами лінійних диференціальних рівнянь другого порядку. Побудований спосіб керування переслідувача на основі інформації про керування втікача в минулому, що забезпечує йому зустріч із супротивником у скінченний момент часу, яке б керування останній не застосовував, та при довільних початкових станах та швидкостях супротивників. Принцип розтягу часу підтвердив, що є ефективним засобом при вирішенні задач, що не піддаються дослідженню класичними прямими методами.

Ключові слова: диференціальна гра, змінне запізнення інформації, умова Понтрягіна, принцип розтягу часу, різниця множин за Мінковським, згасаючі коливання. 